\title{
DEVLETLERİN ÖZEN YÜKÜMLÜLÜĞÜ İLKESI BAĞLAMINDA DENİZLERDE GÖÇMENLERİ KORUMA GÖREVİ
}

\author{
The Duty of Protecting Migrants at Sea in the Context of the Principle of Due \\ Diligence
}

Ayşe GÜNEŞ*

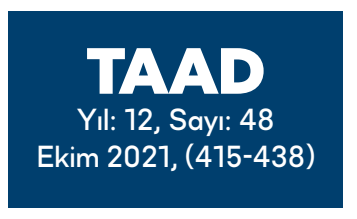

Makale Bilgisi

Geliş Tarihi : 03.05.2021

Kabul Tarihi : 14.09.2021

Makale Türü: Araştırma

\section{$\underline{\text { Article Info }}$}

Received Date: 03.05.2021

Accepted Date: 14.09.2021

Article Type : Research

\begin{abstract}
ÖZET
Göç, bir göçmenin yolculuğunu kapsadığı kadar birçok devleti ve uluslararası aktörü de içine alan ulus ötesi bir olgudur. Son dönemde artmakta olan kitlesel göç hareketi ile birlikte kadınlar ve çocuklar dahil olmak üzere birçok insanın uygun olmayan araçlar ile (tekne, şişme bot) seyahat etmesi sonucu binlerce mülteci ve göçmen denizlerde hayatını kaybetmektedir. Bu makalede, uluslararası insan hakları hukukunun pozitif özen yükümlülüğü ilkesi bağlamında denizlerde göçmenlere (düzensiz göçmen ya da sığınmacılar) karşı koruma görevlerinin yerine getirilmemesi sebebiyle birden fazla devletin sorumluluğunun olabileceği analiz edilmektedir. $\mathrm{Bu}$ analiz, Uluslararası Mülteci Hukuku, Deniz Hukuku ve İnsan Hakları Hukuku arasındaki ilişki ile özen yükümlülüğünün sınırları bağlamında devletlerin göçmenleri koruma sorumluluğu ve denizlerde geri gönderilmemenin ülke dış1 etkisi kapsamında değerlendirilmektedir.
\end{abstract}

Anahtar Kelimeler: Göçmen, Uluslararası Mülteci Hukuku, Uluslararası Deniz Hukuku, İnsan Hakları Hukuku, denizler, Geri gönderilmeme ilkesi, Özen yükümlülügüü.

\begin{abstract}
Migration is a transnational phenomenon that includes many states and international actors as well as encompassing an immigrant's journey. With the recent increasing mass migration movement, many people, including women and children, travel by unsuitable vehicles (boats, inflatable boats) and thousands of refugees and migrants die in the seas. This article analyses that plurality of states have the responsibility of duty to protect migrants (irregular migrants or asylum seekers) at sea within the context of the positive due diligence principle of international human rights law. This analysis is evaluated the extraterritorial effect of the duty to protect migrants and non-refoulement at sea in the context of the relationship between International Refugee Law, Law of the Sea and Human Rights Law and the limits of the due diligence.
\end{abstract}

Key words: Migrant, International Refugee Law, Law of the Sea, Human Rights Law, sea, non-refoulment principle, due diligence

Bu makale Etik Kurul İznine tabi değildir.

* Dr., Bartın Üniversitesi, aysegunes@bartin.edu.tr, https://orcid.org/0000-0001-7429-1531. 
IIIIIIIIII

\section{GİRIŞ}

Son dönemde artmakta olan kitlesel göç hareketi sonucu uygun olmayan deniz araçları (tekne ve bot) vasıtasıyla seyahat ederken kadınlar ve çocuklar da dahil olmak üzere binlerce mülteci ve göçmenin trajik şekilde boğulma ve kaybolma vakalarıyla hem Akdeniz hem de diğer denizlerde karşı karşıya kalmaktayız. ${ }^{1}$ Birleşmiş Milletler Mülteciler Yüksek Komiserliği (BMMYK) verilerine göre en yoğun kitlesel göçün yaşandığı 2015 yılından bu yana Akdeniz'de toplam 18.000 insan hayatını kaybetmiştir. ${ }^{2}$ Uluslararası Göç Örgütü (OIM) 2020 yılında savaştan veya zulümden kaçmak veya daha iyi bir yaşam sürdürmek amaciyla Avrupa'ya ulaşmak için Akdeniz'i geçmek isteyen yaklaşı 1.054 göçmenin öldüğünü veya kaybolduğunu tahmin etmektedir. ${ }^{3}$ Aynı zamanda, Myanmar'dan kaçan binlerce zulüm gören Arakanlı (Rohingya) Müslümanlar da dahil olmak üzere göçmenler (düzensiz göçmen, mülteci ya da sığınmacılar) Bangladeş, Tayland, Malezya ve Endonezya gibi ülkelerin kıyılarında denizlerde mahsur kalmaya devam etmektedirler. ${ }^{4}$ Buna karşın devletler ise hem arama ve kurtarma operasyonlarına katılma konusunda isteksiz davranmakta hem de genellikle göçmenleri taşıyan tekneleri geri itme (push-back) politikalarıyla ülkesel yetki alanlarından uzaklaştırmaya çalışmaktadırlar. ${ }^{5}$ Uluslararası Göç Örgütü Genel Sekreteri Özel Temsilcisi

Guy S. Goodwin-Gill, "Setting the Scene: Refugees, Asylum Seekers, and Migrants at Sea-the Need for a Long-term, Protection-Centred Vision." in Violeta Moreno-Lax, and Efthymios Papastavridis (eds.), Boat Refugees' and Migrants at Sea: A Comprehensive Approach (Brill Nijhoff, 2017) 17-31; Guy S. Goodwin-Gill, 'International refugee law: Where it comes from, and where it's going' (2017) 45 Int'l J. Legal Info. 24; James C. Michelle Hathaway, The rights of refugees under international law (Cambridge University Press, 2005); James C. Hathaway, and Michelle Foster, The Law of Refugee Status (Cambridge University Press, 2014); Mariagiulia Giuffré, "Access to Asylum at Sea? Non-refoulement and a Comprehensive Approach to Extraterritorial Human Rights Obligations", in Violeta Moreno-Lax and Efthymios Papastavridis (eds.), Boat Refugees' and Migrants at Sea: A Comprehensive Approach ( Brill Nijhoff, 2017) 248-275; Seline Trevisanut, 'The Principle of Non-Refoulement And the De-Territorialization of Border Control at Sea'(2014) 27(3) Leiden Journal of International Law, 661-675.

2 Mediterranean: Dead and Missing at Sea, United Nations High Commissioner for Refugees, $<$ http://data2.unhcr.org/en/situations/mediterranean $>$ Erişim tarihi: 12.02.2021; International Organization for Migration, Missing Migrants Project (Web Page) <http:// missingmigrants.iom.int> Erişim tarihi: 12.02.2021.

3 International Organization for Migration, 'December 2020 update - NGO ships involved in search and rescue in the Mediterranean and legal proceedings against them' <https:// fra.europa.eu/en/publication/2020/december-2020-update-ngo-ships-involved-search-andrescue-mediterranean-and-legal> Erişim Tarihi: 12.02.2021.

$4 \quad<$ https://www.bbc.com/turkce/haberler-dunya-41070125>. Erişim Tarihi: 12.02.2021.

5 Özellikle son dönemde Yunanistan'ın göçmenlere karşı illegal geri itme politikaları için bakınız: Bethan McKErnan, "Greece accused of 'shocking' illegal pushback against refugees at sea" (26 April 2021) The Guardian, available at: < https://www.theguardian. com/world/2021/apr/26/greece-accused-of-shocking-pushback-against-refugees-at- 
Peter Sutherland, bu durumu 2015 yılında 'ahlaki bir başarısızlık' olarak değerlendirmiştir. ${ }^{6}$ Göçmenlerin insan olmaları ve dolayısıyla insan olmadan kaynaklı temel hak ve hürriyetlere sahip olmalarına rağmen bu insanların hayatlarını kurtarmak için açık denizlerde harekete geçme noktasında devletlerin isteksiz davranmaları, uluslararası hukukun pozitif normlarıla çelişmektedir. Diğer bir ifadeyle, devletler uluslararası insan hakları hukukuna göre göçmenleri aramak, kurtarmak ve korumak için sorumluluk altındadırlar. Devletler bu görevi, uluslararası insan hakları hukuku, mülteci hukuku ve deniz hukukundaki çeşitli hukuki dayanaklardan yararlanarak, özen gösterme ilkesi çerçevesinde yerine getirmelidirler.

Uluslararası insan hakları hukukunun pozitif özen yükümlülüğü ilkesine dayanarak, devletlerin göçün açık denizlerde ülke dışı etkisini de göz önünde bulundurarak göçmenlere (düzensiz göçmen ya da sığınmacılara) karșı koruma görevi sorumluluğu bu makalenin tartışma konusunu oluşturmaktadır. $\mathrm{Bu}$ tartışma, Uluslararası Mülteci Hukuku, Uluslararası Deniz Hukuku ve İnsan Hakları Hukuku arasındaki ilişkinin özen gösterme yükümlülüğü ilkesi ile birlikte denizlerde geri gönderilmemenin ülke-dış1 etkisi kapsamında yapilacaktır.

Makalenin ilk kısmında, uluslararası hukukunun özen yükümlülüğü ilkesinin kavramsal analizi yapılacaktır. Göçmenleri açık denizlerde koruma görevi, insan hakları hukuku ile deniz hukuku arasındaki ilişki özen gösterme ilkesi çerçevesinde değerlendirilerek makalenin sınırları ikinci kısımda çizilecektir. Üçüncü kısımda, devletlerin göçmenleri koruma yükümlülüğünde kendi karasuları dışında (ülkedış1lık) özen yükümlülüğü ilkesinin uygulanabilirliği tartışılacaktır. Devletlerin denizlerden gelen göçmenleri koruma görevinde geri gönderilmemenin ülke-dışı etkisi özen yükümlülüğü kapsamında olup olmadığ ${ }_{1}$ ise makalenin son kısmında değerlendirilecektir.

\section{Kavramsal Analiz: Özen Yükümlülüğü İlkesi}

Çok genel bir ifadeyle, özen yükümlülüğü ilkesi, olası veya öngörülebilir istenmeyen sonuçlardan kaçınmak için gereken bir davranış standardı anlamına gelmektedir. Özen yükümlülüğ̈̈ ilkesi yasal sorumlulukları yerine

sea?CMP=Share_iOSApp_Other> Erişim Tarihi: 28.04.2021; Kathy Fallon, "We were left in the sea': asylum seekers forced off in Lesbos", (19 March 2021) The Guardian, available at: < https://www.theguardian.com/global-development/2021/mar/19/asylumseekers-forced-off-lesbos-pushback-crisis-europe-borders> Erişim Tarihi: 18.04.2021; Helena Smith, "Cyprus rebuked for 'violent' pushbacks of boats carrying asylum seekers", (18 March 2021) The Guardian, available at: < https://www.theguardian.com/world/2021/ mar/18/watchdog-criticises-cyprus-treatment-asylum-seekers> Erişim Tarihi: 18.04.2021.

6 Remarks by Peter D. Sutherland, UN Special Representative for International Migration Before the United Nations Security Council,May 11, 2015, <https://www. un.org/en/development/desa/population/migration/partners/docs/Remarks_by_SRSG_ PeterSutherland_on_SecurityCouncil.pdf.> Erişim Tarihi: 12.02.2021. 
IIIIIIIIII!

getirmek için gerekli olan bir davranışı tasvir etmek için bir dizi uluslararası antlaşmaya konu edilmiş̧ir.' ${ }^{7}$ Aynı zamanda üçüncü şahıslar tarafindan yapılan hukuka aykırı müdahalelere karşı bu müdahalelere maruz kalan kişileri koruma ve herhangi bir zarar meydana gelmişse sorumlu kişileri cezalandırma hususunu da kapsamına alarak görev sahibine harekete geçme yükümlülüğü getirmektedir. ${ }^{8}$ Nitekim bu ilke görev sahibi tarafindan kendi davranışıyla ilgili olarak üstlenilebilecek ve ayrıca bir sonuç yükümlülüğü içerebilecek herhangi bir görevden farklı olarak değerlendirilmektedir. ${ }^{9}$

Genel olarak uluslararası hukukta, özen yükümlülüğ̈̈ standardının uzun bir geçmişi vardır. Kamminga'ya göre bu ilke, geleneksel olarak, yabancılara muamele edilmesi hususunda uluslararası kurallar çerçevesinde belirlenen asgari standardın bir parçası olarak algılanmaktadır. ${ }^{10}$ Ancak bu standart hem uluslararası mahkemelerin hem de bölgesel mahkemelerin davalarında gelişen bir ilke olarak kendine yer bulmuştur. Örneğin, Uluslararası Adalet Divanı insan hakları davasında özen gösterme ilkesine ilişkin olarak Bosna Soykırımı davasında $^{11}$, Soykırımı Önleme ve Cezalandırma Sözleşmesi (Soykırım Sözleşmesi) ${ }^{12}$ kapsamında soykırımı önleme yükümlülügüne ilişkin olarak şöyle bir karar vermiştir:

[...] bir devletin koşullar ne olursa olsun, soykırımın işlenmesini önleme konusunda özen yükümlülüğü altında olmaması durumunda söz konusu yükümlülüğün bir sonuç değil, davranış olduğu açıktır. Devletlerin yükümlülüğü soykırımı olabildiğince önlemek için makul olarak ellerinde bulunan tüm araçları kullanmaktır. [...] Devlet, soykırımı önlemeye katkıda bulunabilecek soykırımı önlemek için yetkisi dahilindeki tüm önlemleri açıkça almadıysa sorumluluk doğar. Bu alanda, somut bir değerlendirme gerektiren "gerekli özen gösterme" kavramı kritik öneme sahiptir. ${ }^{13}$

Jan Arno Hessbruegge, 'The Historical Development of the Doctrines of Attribution and Due Diligence in International Law', (2004) 36 N.Y.U. J. INT'L L. \& POL. 265.

8 Jonathan Bonnitcha \& Robert McCorquodale, "The Concept of "Due Diligence" in the UN Guiding Principles on Business and Human Rights', (2017) 28(3) EUR. J. INT’L L. 899.

9 ibid.

10 Menno T. Kamminga, “Due diligence” Mania: The Misguided Introduction of an Extraneous Concept into Human Rights Discourse', in Ingrid Westendorp (ed.), The Women's Convention Turned 30 (Maastricht Faculty of Law Working Paper No. 2011/07, 2012) 407-417.

11 International Court of Justice, Case Concerning the Application of the Convention on the Prevention and Punishment of the Crime of Genocide, (judgement of 26 February 2007).

12 Soykırımı Önleme ve Cezalandırma Sözleşmesi (Convention on the Prevention and Punishment of the Crime of Genocide, opened for signature Dec. 9, 1948), 78 U.N.T.S. 277 (yürürlülük tarihi: 12 Ocak 1951).

13 International Court of Justice, Case Concerning the Application of the Convention on the Prevention and Punishment of the Crime of Genocide, (judgement of 26 February 2007), para. 430. 
Soykırım Sözleşmesi, soykırımı önleme ve cezalandırma görevini ortaya koymaktadır. ${ }^{14}$ Bosna Soykırımı davasında Uluslararas1 Adalet Divanı, Sırbistan'ın uluslararası sorumluluğu hususunda zararın meydana gelmesini önlemek için makul olan tüm araçları kullanmakta gerekli özeni göstermemekle ilişkilendirilmiştir. ${ }^{15}$ Bir devletin veya başka bir görev sahibinin, kötü sonucun ortaya çıkmasının risklerini önlemek için makul önlemleri alarak gerekli özeni gösterme yükümlülügü vardır. Bu hususta gerekli makul adımlar olarak kabul edilecek olanlar, özeni gösterme yükümlülüğünün nasıl çerçevelendirildiğine, riskleri destekleyen özel şartlara ve görev sahiplerinin eylem kapasitelerine ve firsatlarına bağlı olacaktır. Bir yükümlülüğün yerine getirilmesini gerektiren bir davranış standardı olarak özen yükümlülüğü ilkesi bu bağlamda yardımcı olmaktadır. Özen yükümlülüğü ilkesi, uluslararası hukukun pek çok farklı alanının temel bir özelliği olmuştur; ki bununla birlikte, uluslararası hukuk 'özen gösterme' terimini nadiren kullanmaktadır. ${ }^{16}$

BM insan hakları hukuku sisteminde özen yükümlülüğü daha çok sayg1 gösterme, koruma ve yerine getirme yükümlülükleri çerçevesinde kullanılmaktadır. Örneğin, Uluslararası Medeni ve Siyasi Haklar Sözleşmesinde (ICCPR), "Bu sözleşmenin her bir Tarafı, bu sözleşmede tanınan haklara saygı göstermeyi ve [...] sağlamayı taahhüt eder" ${ }^{\prime 17}$ şeklinde bir ifade ile bu durumu arzetmektedir. Aynı zamanda, Avrupa İnsan Hakları Sözleşmesi’nin (AİHS) 1. maddesinde "Yüksek Sözleşmeci Taraflar, kendi yetki alanları dahilindeki herkese bu Sözleşmenin 1. bölümünde tanımlanan hak ve özgürlükleri temin edeceklerdir" ifadesi yer almaktadır. Hakkı güvence altına alma yükümlülüğü, Avrupa İnsan Hakları Mahkemesi (AİHM) tarafindan zamanla taraf devletlere pozitif tedbirler alma yönünde pozitif yükümlülükler yüklediği şeklinde yorumlanmaktadir. ${ }^{18}$

İnsan hakları hukuku kapsamında özen yükümlülüğü ilkesine en çok devletler ve devlet dışı aktörler tarafindan (özel şahıslar, silahlı muhalefet grupları veya tüzel kişiler) şiddeti önleme, durdurma ve bunlara yanıt verme çabaları kapsamında başvurulmuştur. ${ }^{19}$ Sadece önleme yükümlülüğünü değil, aynı zamanda cezalandırma, soruşturma veya verilen zararı telafi etme

14 Madde 1, Soykırımı Önleme ve Cezalandırma Sözleşmesi.

15 Application of the Convention on the Prevention and Punishment of the Crime of Genocide (B.H. v. S.M.), Judgment, 2007 I.C.J. 43, para. 471 (5).

16 Duncan French and Tim Stephens (Rapporteurs), International Law Association Study Group on Due Diligence in International Law, ILA Study Group, First Report, 7 March 2014, 6 .

17 Madde 2(1) Uluslararası Medeni ve Siyasi Haklar Sözleşmesi (ICCPR).

18 Opuz v Turkey (App no 33401/02, Judgement of 9 June 200) para. 159.

19 Yakın Ertürk, (Special Rapporteur on Violence Against Women, its Causes and Consequences), 'The Due Diligence Standard as a Tool for the Elimination of Violence Against Women', U.N. Doc. E/CN.4/2006/61 (Jan. 20, 2006), para. 35. 
IIIIIIIIII!

yükümlülügünü de içermektedir. ${ }^{20}$ Örneğin, AİHS'nin 3. maddesi, devletlerin suç işlemekten kaçınma yükümlülügüne ek olarak, işkence ve diğer zalimane insanlık dışı muamele biçimlerini teşkil edecek bir zarar söz konusu olduğunda, bir devletin veya özel aktörlerin neden olduğu bu tür zararları önlemek ve önlenemediği durumlarda ise etkili bir şekilde soruşturma ve cezalandırma hususunda pozitif özen yükümlülüklerini de saymaktadır. ${ }^{21}$ Benzer pozitif yükümlülükler yaşam hakk1 için tespit edilmiştir. Örneğin, Opuz/ Türkiye davasında, AİHM, Türkiye'nin başvuranın annesinin öldürülmesini önlemek için gerekli özeni gösterme zorunluluğunu yerine getirmediğini ifade etmiştir. ${ }^{22}$ İlgili dava kapsamında AİHM, Türkiye'yi başvuranın eşine yönelik cezai yargılamayı sonlandırdığı ve sanığı tutuklamadığı, şiddet içeren tehditler ile ilgili olarak koruyucu önlemler veya diğer uygun önlemleri almadığ 1 yani gerekli özen yükümlülüğünü yerine getirmediği için başarısız bulmuştur. ${ }^{23}$

Makalenin ikinci kısmında, açık denizlerde göçmenlerin insan haklarını koruma görevinde devletlerin özen gösterme yükümlülügünü, insan hakları hukuku ve deniz hukuku arasındaki ilişkinin sınırları hem uluslararası kuruluşların aldıkları kararlar (BM Güvenlik Konseyi) hem de uluslararası sözleşmeler (BMDHS, SOLAS, SAR) çerçevesinde değerlendirilecektir.

\section{2. İnsan Hakları Hukuku ile Deniz Hukuku Arasındaki İlişki Bağlamında Özen Gösterme Yükümlülüğü İlkesinin Analizi}

Devletlerin göçmenleri koruma görevinin ülke dişı etkisi ile eşzamanlı olarak sınırlarını koruyucu bir şekilde hareket etmesi noktasında koruma kavramı anahtar bir unsur olarak karşımıza çıkmaktadır. O nedenledir ki, uluslararası hukukta koruma yükümlülügü, insan haklarının geliştiği alanlardan birine karşılık gelir ki, daha geniş kapsamlı olarak özen yükümlülüğü kavramıyla ilişkilendirilmektedir. ${ }^{24}$ Özen yükümlülüğü ilkesi devletlerin, ilgili kişinin statüsü (uyruğu veya vatansızlık gibi) ne olursa olsun, insan hakları ihlalini önleyici ve daha çok genel olarak koruyucu amaçlar çerçevesinde, proaktif olmasını gerektirir. ${ }^{25}$ Ayrıca özen yükümlülüğü davranış yada araç

20 UN Human Rights Committee, 'General Comment No. 31: The Nature of the General Legal Obligation Imposed on States Parties to the Covenant', U.N. Doc. CCPR/C/21/Rev.1/Add. 13 (May 26, 2004), para. 8.

21 Vladislava Stoyanova, 'Causation between State Omission and Harm within the Framework of Positive Obligations under the European Convention on Human Rights' (2018) 18 Human Rights Law Review 309-346.

22 Opuz / Türkiye (Başvuru no. 33401/02, Karar Tarihi: 8 Haziran 2009) (Opuz v Turkey, App no 33401/02, Judgement of 9 June 200) paras. 137-49.

23 Opuz / Türkiye (Başvuru no. 33401/02, Karar Tarihi: 8 Haziran 2009) (Opuz v Turkey, App no 33401/02, Judgement of 9 June 200) paras. 137-49.

24 Robert P. Barnidge, 'The Due Diligence Principle under International Law', 8 International Community Law Review (2006) 81-122

25 Osman/UK (Başvuru no. 23452/94, Karar tarihi: 28 Ekim 1998) (Osman v. UK, (Application 
yükümlülüklerini de belirlemektedir. Devletlerin, koruma yükümlülüğü hedefleri doğrultusunda ellerinden gelenin en iyisini gerçekleştirmek için kendilerine sunulan araçları kullanmaları beklenmektedir.

İnsan hakları hukukunun pozitif yükümlülüğ̈̈ olarak koruma görevi ya da gerekli özen yükümlülüğ̈̈ özellikle insan hayatını korumada, insan hakları hukuku hükümlerinin ötesinde belirli anlaşmalardan veya uluslararası kuruluşların uygulamalarından kaynaklanabilmektedir. Örneğin, Güvenlik Konseyi, BM Şartı 7. Bölümü uyarınca, denizde "göçmenlerin veya insan kaçakçılı̆g kurbanlarının, tehdit altındaki hayatlarını kurtarmayı" amaçlayan 2015 tarihli Libya'dan botlarla hareket ederek Akdeniz'de trajik göçmen kayıpları konusunda 2240 sayılı kararı kabul etmiştir. ${ }^{26}$ Güvenlik Konseyi, aldığ bu kararla, devletlere "açık denizlerde, Libya açıklarında şüphelenmek için makul gerekçeleri bulunan göçmen kaçakçıllğg 1 veya insan kaçakç1lığ için kullanıldığ 1 gemileri inceleme" yetkisi vermektedir. ${ }^{27}$ Benzer şekilde, Güvenlik Konseyi ilgili yargılama yetkisine sahip devletleri denizde göçmen kaçakçılığ 1 ve insan ticareti eylemlerinden sorumlu kişileri soruşturmaya ve kovuşturmaya davet etmektedir. ${ }^{28}$

Dahası, insan hakları hukuku dışında devletlere göçmenleri koruma yükümlülüğü getiren birçok uluslararası anlaşma mevcuttur. Örneğin, Birleşmiş Milletler Sınıraşan Örgütlü Suçlarla Mücadele Sözleşmesini Tamamlayan Kara, Deniz ve Hava Yoluyla Göçmen Kaçakçılığına Karş1 Protokol'ün 16. Maddesi, kaçakçıllığa maruz kalmış kişilerin haklarını ve özellikle yaşam haklarını koruma görevini düzenlemektedir. ${ }^{29}$ Ayrıca uluslararası deniz hukuku, denizde göçmenlerin yaşam haklarını korunması için uygun hukuki dayanaklar sunan uluslararası hukukun özel geleneksel veya antlaşmadan kaynaklanan kurallarını içermektedir. ${ }^{30}$ Örneğin, bir taraf devletin

No. 23452/94, Judgment of 28 October 1998); Velásquez- Rodriguez / Honduras, Amerikalılar Arası İnsan Hakları Sistemi, Karar tarihi: 29 Temmuz 1988) (VelásquezRodriguez v. Honduras, Judgment, Inter-American Court of Human Rights Series C No. 4, 29 July 1988), para. 172.

26 BM Güvenlik Konseyi Rezolüsyon 2240 (UN Security Council Resolution 2240) (9 October 2015) UN Doc. s/res/2240. <http://unscr.com/files/2015/02240.pdf > Erişim Tarihi: 22.02.2021.

27 BM Güvenlik Konseyi Rezolüsyon 2240 (UN Security Council Resolution 2240) 9 October 2015) UN Doc. s/res/2240, para. 7.

28 BM Güvenlik Konseyi Rezolüsyon 2240 (UN Security Council Resolution 2240) (9 October 2015) UN Doc. s/res/2240, para. 15.

29 Article 16(3), Sınıraşan Örgütlü Suçlara Karşı BM Sözleşmesine Ek Kara, Deniz ve Hava Yoluyla Göçmen Kaçakçıllı̆̆ Karşı Protokol, 5 Kasım 2000, UNTS 2241 (Protocol against the Smuggling of Migrants by Land, Sea and Air Supplementing the United Nations Convention against Transnational Organized Crime, 15 November 2000, UNTS 2241).

30 Richard Barnes, 'Refugee Law at Sea', (2004) 53 International and Comparative Law Quarterly 48-61. 
IIIIIIIIII!

bayrağını taşıyan gemilerin açı denizlerde tehlikede olan kişilere ve gemilere yardım etme görevini belirleyen ve uluslararası teamül hukukuna da dahil olarak görev sayılan 1982 Birleşmiş Milletler Deniz Hukuku Sözleşmesi'nin (BMDHS) $)^{31}$ 98. Maddesinde düzenlenen "Yardım etme yükümlülüğü" şu şekilde açıklanmaktadır:

1. Her devlet kendi bayrağını taşıyan bir geminin, kaptanından, gemi mürettebat ve yolcular için ciddi bir tehlike oluşturmadan ifa edilebilecek ise, aşağıdaki hususları gerçekleştirmesini talep edecektir.

- Denizde tehlike içerisinde bulunan her kişiye yardım etmek;

- Yardım ihtiyaçlarından haberdar edildiği takdirde, tehlikede bulunan kişileri, kendisinden makul olarak beklenebilen ölçüde ve mümkün olduğu kadar çabuk kurtarmaya gitmek;

- Bir çarpışmada sonra, diğer gemiye, mürettebatına ve yolcularına yardımda bulunmak ve mümkün olduğu ölçüde kendi gemisinin adını, tescil limanını ve uğrayacağı en yakın limanı diğer gemiye bildirmek..$^{32}$

BMDHS aynı zamanda kıyı devletlerine denizde ve üzerinde etkili arama ve kurtarma mekanizmalarını teşvik etme yükümlülüğü getirmektedir. ${ }^{33}$ BMDHS'nin ötesinde, 1989 Uluslararası Kurtarma Sözleşmesi³ ${ }^{34}, 1974$ tarihli Denizde Can Güvenliği Uluslararası Sözleşmesi (SOLAS) ${ }^{35}$ ve daha fazla sayıda imzacı çekmek için 1998'de değiştirilen 1979 tarihli Denizde Arama ve Kurtarma Uluslararası Sözleşmesi (SAR) ${ }^{36}$ gibi sözleşmeler bu kapsamda sayılabilir. ${ }^{37}$ SAR Sözleşmesi'nin temel amacı, denizdeki kurtarma operasyonlarının koordinasyonunu kolaylaştırmaktır. SAR ve daha genel olarak deniz hukuku, "denizde kurtarılma hakkı" için hukuki dayanaklar olarak

31 BM Deniz Hukuku Sözleşmesi (United Nations Convention on the Law of the Sea (UNCLOS), 10 December 1982, unts 1833). Türkçe metni için bakınız: <http://www. turkishgreek.org/kuetuephane/item/153-unclos-turkish> Erişim Tarihi: 02.03.2021.

32 Madde 98, BM Deniz Hukuku Sözleşmesi (UNCLOS).

33 Madde 98 (2) :"Sahili bulunan bütün devletle, deniz ve hava güvenliğini sağlamak üzere uygun ve etkili bir sürekli arama ve kurtarma servisinin kurulmasını ve işleyişini kolaylaştıracaklar ve gerektiği takdirde bu amaçla komşu devletlerle bölgesel düzenlemeler çerçevesinde işbirliğinde bulunacaklardır.”, BM Deniz Hukuku Sözleşmesi (UNCLOS).

341989 Uluslararası Kurtarma Sözleşmesi (International Convention for the Safety of Life at Sea, 1 November 1974, UNTS. 1184).

351974 tarihli Denizde Can Güvenliği Uluslararası Sözleşmesi (International Convention on Salvage, 28 April 1989, UNTS. 1953).

361979 Denizde Arama ve Kurtarma Uluslararası Sözleşmesi (International Convention on Maritime Search and Rescue, 27 April 1979, UNTS. 1403).

37 Sözleşmeler için bakınız: $<$ https://www.imo.org/en/About/Conventions/Pages/ListOfConventions.aspx $>$ Erişim Tarihi: 02.03.2021. 
sayılabilmektedir. ${ }^{38}$ Öyle ki, uluslararası deniz hukuku kapsamında bulunan bu sözleşmeler farklı hedefler ve amaçlar doğrultusunda sınıflandırılmışlardır. Ancak bu sinıflandırma aynı zamanda, uluslararası insan hakları hukuku ve uluslararası mülteci hukuku gibi diğer hukuk alanlarının yansıtarak ayrımcılık yapmamanın önemi gibi insani değerler ile bağlantılı bazı önemli özelliklerinin altını çizmeye yardımcı olmaktadır. Denizlerde yardım etme görevi, denizde tehlikede olan düzensiz göçmenleri, sığınmacıları da kapsayarak herkes için geçerlidir. BMDHS'nin 98 (1) maddesi "denizde kaybolma tehlikesiyle karş1 karşıya bulunan herhangi bir kişiye" atıfta bulunurken, SOLAS Sözleşmesi ${ }^{39}$ ve SAR Sözleşmesi ${ }^{40}$ aynı ve benzer bir şekilde ayrımcılık yasaklarını içermektedir. $\mathrm{Bu}$ yönleriyle deniz hukuku kapsamındaki bu sözleşmeler, devletlerin denizlerde yaşam hakkı tehlikede bulunan kişilere karşı pozitif koruma yükümlülüğünde gerekli özeni göstermelerini gerektirmektedir. Diğer bir ifadeyle, deniz hukukunun sözleşmelerindeki bu maddeler ve devletler için belirtilen bu yükümlülükler özen yükümlülüğü olarak yorumlanmaktadır. ${ }^{41}$

İnsan hakları sadece insanın temel hakkı olan yaşam hakkıyla ilgili değildir. Bir örnek ile açıklamak gerekirse, geri göndermeme (non-refoulement), mülteci hukukunda bir 'temel koruma ilkesi' ${ }^{42}$ olarak göçün merkezi bir prensibi olarak kabul edilmektedir. ${ }^{43}$ Geri göndermeme ilkesi (non-refoulement principle), AİHM tarafından hem yaşam hakkı hem de işkence, aşağılama ve insanlık dışı muamele yasağı ile ilişkili bir insan hakları standardı olarak kabul

38 Seline Trevisanut, 'Is There a Right to Be Rescued At Sea? A Constructive View', (June 2014) 4 Questions of International Law 3, 5-8.

40 SAR Convention annex para 2.1.10.

${ }^{41}$ Lisa-Marie Komp, "The Duty to Assist Persons in Distress: An Alternative Source of Protection against the Return of Migrants and Asylum Seekers to the High Seas?", in Violeta Moreno-Lax and Efthymios Papastavridis (eds.), 'Boat Refugees' and Migrants at Sea: A Comprehensive Approach, (Brill Nijhoff, 2017) 237; Douglas Guilfoyle, "Transnational crime and the rule of law at sea: responses to maritime migration and piracy compared", in Violeta Moreno-Lax and Efthymios Papastavridis (eds.), 'Boat Refugees' and Migrants at Sea: A Comprehensive Approach, Brill Nijhoff, 2017) 179.

42 UNHCR, 'Note on international protection' (13 September 2001) a/ac.96/951, para. 16

43 Madde 33, 1951 tarihli Mültecilerin Hukuki Statüsüne İlişkin Sözleşme (Convention Relating to the Status of Refugees).

Madde 33 (1): "Hiç bir taraf devlet, bir mülteciyi, rrk1, dini, tabiiyeti, belli bir sosyal gruba mensubiyeti veya siyasi fikirleri dolayısıyla hayatı ya da özgürlügü tehdit altında olacak ülkelerin sınırlarına, her ne şekilde olursa olsun geri göndermeyecek veya iade ("refouler") etmeyecektir".

Madde 33 (2): "Bununla beraber, bulunduğu ülkenin güvenliği için tehlikeli sayılması yolunda ciddi sebepler bulunan veya özellikle ciddi bir adi suçtan dolayı kesinleşmiş bir hükümle mahkum olduğu için söz konusu ülkenin halkı açısından bir tehlike oluşturmaya devam eden bir mülteci, işbu hükümden yararlanmayı talep edemez." 
IIIIIIIIII!

edilmiştir. ${ }^{44} 1951$ Mülteci Sözleşmesi'nin 33. Maddesinin de ötesine geçen mümkün olan en geniş şekilde "geri göndermeme" kavramı, devletlerin, bir kişiyi ciddi insan hakları ihlallerine maruz kalma riskinin bulunduğu bir yere geri göndermeme ya da nakletmeme görevi (yani iade etme, sınır dışı etme, vb.) olarak tanımlanmaktadır. ${ }^{45}$ Yaşam hakkı ve kötü muamele yasağ olarak, uluslararası insan hakları hukuku, özellikle bu kişilerin, bu tür insan hakları ihlallerinin meydana gelebileceği bir devlete geri gönderilmemelerini şart koşmaktadır. ${ }^{46} \mathrm{Bu}$ nedenle, (deniz yoluyla) göç, kurtarmanın ötesinde, insan haklarının korunmasına ilişkin bir dizi sorumluluğu yani pozitif yükümlülügü gündeme getirmektedir. Bir sonraki başlıkta, devletlerin göçün ulus ötesi doğası sebebiyle ülkesel yarg1 yetkilerinin ötesinde (ülke-dış1lık) açık denizlerde göçmenleri koruma görevinde birden çok devletin özen yükümlülüğü bağlamında sorumlu olabileceği analiz edilecektir.

\section{Devletlerin Göçmenleri Koruma Görevi: Özen Yükümlülüğü ve Ülke-dışılık Etkisi}

Göç insanlık kadar eski bir kavramdır. ${ }^{47}$ İnsanlar bir yerden başka bir yere sosyal, ekonomik ya da siyasi sebeplerle evlerini/yurtlarını yeni bir yer/yurt haline getirme niyetiyle taşırlar. ${ }^{48}$ Bununla birlikte, yeni bir yuva kurmadan önce, göçmenler uyruğu oldukları ülkeleri terk etmek zorundadırlar. Öyle ki, sınırları geçmeleri, diğer devletlerin topraklarından veya tüm uluslara açık olan ve hiçbir devletin egemenlik hakkı olmadığı açık denizlerden geçmeleri gerekebilir. Göç, bir göçmenin yolculuğunu kapsadığı kadar birçok devleti ve ayrıca ilgili tüm aktörlerin vatandaşlık durumlarını içeren ulus ötesi incelenmesi gerekli bir alandır. Ancak gittikleri topraklar, hedef devletin ya da ev sahibi devletin egemenlik yetkisinde olacaktır. Bir kişi bir devletin topraklarına yasal veya yasadışı olarak - girdiğinde, mülkilik prensibi gereği o devletin ülkesel yarg1 yetkisi altında olmaktadır. ${ }^{49}$ Bir göçmenin bulunduğu topraklarda

44 M.S.S / Belçika ve Yunanistan ( Başvuru no. 30696/09, Karar tarihi 21 Ocak 2011) (M.S.S v Belgium and Greece, Application No. 30696/09, Judgment of 21 January 2011), para. 286 and 293.

45 Madde 33, 1951 tarihli Mültecilerin Hukuki Statüsüne İlişkin Sözleşme

46 UNHCR, 'Note on international protection' (13 September 2001) a/ac.96/951, para. 16.

47 William H. MCNEILL, 'Human Migration in Historical Perspective', (1984) 10 (1) Population and Development Review 1, 1-18.

48 Aslı Ş. ÖNER, "Göç Çalışmalarında Temel Kavramlar”, in Aslı Ş. ÖNER ve Gülfer Ihlamur Öner (edt.), Küreselleşme Çağında Göç: Kavramlar, Tartışmalar (İstanbul: İletişim Yayınları, 2012) 13-27, Sami ÖNGÖR, Coğrafya Terimleri Sözlüğü, (Ankara: Türk Dil Kurumu Yayınları, 1980) <http://tdkterim.gov.tr/>, Erişim Tarihi: 16.02.2017.

49 Bankovic ve diğerleri / Belçika, Çek Cumhuriyeti, Danimarka, Fransa, Almanya, Yunanistan, Macaristan, İrlanda, İzlanda, İtalya, Lüksemburg, Hollanda, Norveç, Polonya, Portekiz, İspanya, Türkiye ve Birleşik Krallık, (Başvuru no. 52207/99, Karar Tarihi: 12 Aralık 2001), (Bankovic and others v. Belgium, the Czech Republic, Denmark, France, Germany, Greece, Hungary, Iceland, Italy, Luxembourg, the Netherlands, Norway, Poland, Portugal, Spain, 
ev sahibi devlet, onun üzerinde münhasır yarg1 yetkisine sahip olacaktır. Ev sahibi devlet, ülkesel yargı yetkisi sebebiyle aynı zamanda göçmenlerin insan haklarını koruma hususunda da yükümlülük altında olacaktır. Devletler, göçmenlere karşı herhangi bir insan hakkı ihlalini önlemek ve daha genel olarak göçmenlerin temel insan haklarını korumak için özen yükümlülüğü altındadır.

Göçün ulus ötesi doğası gereği, göçmenleri koruma yükümlülüğü söz konusu olduğunda, devletlerin sınır-ötesi yani ülke dişı yargılama yetkisi söz konusu olmaktadır. Koruma yükümlülüğü, özen yükümlülüğü ilkesiyle bağlantılıdır. ${ }^{50} \mathrm{Bu}$ husus uluslararası insan hakları hukukunda iyi tanınan bir ilkedir ve devletlerin kendi yargı yetki alanları dahilindeki hakları korumak için harekete geçme yükümlülüğü ile ilişkilidir. ${ }^{51}$ Öyle ki, devletlerin hem tarafsız olması ve haksız fiile neden olmaktan kaçınması hem de proaktif olarak ihlali önlemek ve cezalandırmak için kendilerine sunulan araçlardan yararlanmaları gerekmektedir. Uluslararası hukukun yanı sira Uluslararası Haksız Fiillerden Ötürü Devletin Uluslararası Sorumluluğu Taslak Metin'de ${ }^{52}$ bu hüküm yer almaktadır. Diğer bir ifadeyle, devletlerin, örneğin başka kişiler tarafından işlenen ihlalleri önlemek veya sona erdirmek için gerekli önlemleri alma görevleri yani sorumlulukları vardır. İnsan hakları hukuku bağlamında değerlendirildiğinde, insan haklarının pozitif etkisi çerçevesinde koruma görevi ile özen yükümlülüğü ilkesinin bağlantılı olduğu ortaya çıkmaktadır. ${ }^{53}$

Zorla yerinden ettirilen göçmenler yada başka ülkelere göç etmek isteyen bir göçmenin haklarına yönelik (iade, sınır dışı etme, vb.) tehdit, diğer ülkede yani hedef ülkede karşılaşacağı durumlardan da kaynaklanabilmektedir. Göçmenler, hedef yada ev sahibi ülkelerin yetkililerinin davranışları nedeniyle ciddi insan hakları ihlallerine maruz kalma riskiyle karşılaşabilmektedir. ${ }^{54}$ Ayrıca göçmenlerin insan hakları ihlallerine, ev sahibi devletin topraklarındaki üçüncü şahıslar yani diğer şahıslar neden olabileceği gibi doğal olaylar ve sosyal olgular (savaş, yoksulluk) gibi genel durumlar da neden olabilmektedir. Her iki durumda da bir göçmeni hedef devlete aktaran transit (geçiş) devletin, koruma

Turkey and the United Kingdom, Application No. 52207/99, 12 December 2001), para. 59.

50 Riccardo Pisillo Mazzeschi, 'The Due Diligence Rule and the Nature of the International Responsibility of States', (1992) 35 German Yearbook of International Law 9-51; Osman / UK, Velásquez- Rodriguez / Honduras, para. 172.

51 Louise Arbour, 'The Responsibility to Protect as a Duty of Care in International Law and Practice', (2008) 34 Review of International Studies 445, 452.

52 Uluslararası Haksız Fiillerden Ötürü Devletin Uluslararası Sorumluluğu Taslak Metin /Draft Articles on Responsibility of States for Internationally Wrongful Acts with Commentaries 2001, Yearbook of the International Law Commission, 2001, <https://legal.un.org/ilc/texts/ instruments/english/commentaries/9_6_2001.pdf> Erişim Tarihi: 12.02.2021.

53 ibid., İkinci Kısım, 39.

54 Göz altına alma merkezleri ile ilgili AİHM kararı için bakınız: M.S.S / Belçika ve Yunanistan, paras. $205-234$ 
IIIIIIIIII!

ve taşınması / aktarılmasıyla ilişkili tehlikelere maruz kalmasına izin vermeme yükümlülüğüne sahiptir. ${ }^{55} \mathrm{Bu}$ durum, geçiş devletin veya hedef devletin ülkesel yarg1 yetki alanında bulunan bir göçmenin insan haklarının ihlalini önlemek için geri göndermeme ilkesinin ${ }^{56}$ önemini göstermektedir. Geçiş (transit) devletin, kendi topraklarından çıkarmak istediği veya topraklarından başka bir yere transfer etmek istediği kişi için var olan riski değerlendirmek için özen gösterme yükümlülüğü vardır. Ayrıca hedef devlette göçmenin temel hakları için (yaşam hakkı gibi) bir tehlike varsa yani hedef ülke göçmen için güvenli bir varış noktası değilse geçiş devleti, göçmenin tehlikeye maruz kalmasını önlemekte özen göstermelidir. ${ }^{57}$

Göçmenlerin insan haklarının korunmasında özen yükümlülüğ̈̈ ilkesinin diğer bir önemli noktası ise devletlerin yarg1 yetkisinin kaynağı kendi bölgesi veya faaliyet alanının ötesinde olması yani ülke-dış1/sınır-ötesi yargı yetkisinin bulunmasıdır. Devletin bir ülkede veya insanlar üzerinde "gerçek otorite ve kontrol uygulaması", uluslararası insan hakları belgelerinde yargı yetkisi olarak tanımlanmaktadır. ${ }^{58}$ Ancak, ülkesellik uluslararası hukukta yarg1 yetkisi kullanımının kaynağ1 olarak kabul edilmemektedir. ${ }^{59}$ Bilindiği üzere günümüzde modern göç, kaçakçılar tarafından yardım edilerek kolaylaştırılmaktadır. Örneğin, göçmen kaçakçılığı ve insan ticaretini önleme ile ilgili olarak uluslararası sorumluluk, kaçakçının uyruğu, bayrağını taşıdığı devletin teknesi, mağdurun uyruğu olan devlet(ler), göçmenin uyruğu, kaçakçının teknesinin seyrettiği sulardaki devlet, hedef ve menşe devletler, arasında paylaştırılan bir devletler çemberi olarak karşımıza çıkmaktadır. ${ }^{60}$ BM Güvenlik Konseyi ortak sorumluluğu "tüm göçmenlerin insan haklarının geliştirilmesi ve korunmasında menşe, geçiş ve hedef ülkelerinin rolleri ve sorumlulukları" ifadesiyle tanımlamaktadır. ${ }^{61}$ Göçmenlerin insan hakları ve öncelikle yaşam haklarının ihlali tehlikesi söz konusu olduğunda bu tehlikeyi önleme görevi birçok devletin sorumluluğunda olabilmektedir.

M.S.S / Belçika ve Yunanistan, para. 286 ve özellikle para. 293.

Madde 33, 1951 tarihli Mültecilerin Hukuki Statüsüne İlişkin Sözleşme.

57 Othman (Abu Qatada) / United Kingdom, (Başvuru no. 8139/09, Karar tarihi: 17 Ocak 2012) (Othman (Abu Qatada) v. United Kingdom, Application No. 8139/09, Judgment of 17 January 2012), para. 194. AİHM, "Birleşik Krallık ve Ürdün Hükümetlerinin, başvuranın Ürdün'e döndükten sonra kötü muameleye maruz kalmamasını sağlamak için şeffaf ve ayrıntılı güvenceler elde etmek ve sağlamak için gerçek çaba sarf ettiğini” değerlendirdiğini açıklamaktadır.

58 Marko Milanovic, Extraterritorial Application of Human Rights Treaties: Law, Principles, and Policy (Oxford University Press, 2011) 8.

59 Christopher Stalker, 'Jurisdiction', in M.D. Evans (ed.), International Law (4th edn, Oxford University Press, Oxford, 2014) 309-335.

60 BM Güvenlik Konseyi Rezolüsyon 2240.

${ }^{61}$ BM Güvenlik Konseyi Rezolüsyon 2240, Giriş. 
Göçmen kaçakçılığı, 2000 tarihli Sınıraşan Örgütlü Suçlara Karşı BM Sözleşmesine Ek Kara, Deniz ve Hava Yoluyla Göçmen Kaçakçılığ1 Karş1 Protokol'de "doğrudan veya dolaylı olarak, mali veya diğer bir maddi çıkar elde etmek için, bir kişinin vatandaşlığını taşımadığı veya daimi ikametgah sahibi olmadığı bir Taraf Devlete yasadışı girişinin temini" olarak tanımlanmıştır. ${ }^{62}$ Dahası, BM Güvenlik Konseyi 2240 Sayılı Kararı'nda, devletlerin "göçmen kaçakçılığını ve insan ticaretini önlemek ve bunlarla mücadele etmek, failleri soruşturmak ve cezalandırmak, insan ticareti mağdurlarını ve göçmenleri belirlemek ve onlara etkili yardım sağlamak ve insan ticareti ve göçmen kaçakçılığ 1 önlemek ve bastırmak için mümkün olan en geniş kapsamda işbirliği yapmak için gerekli özeni gösterme" görevi olduğunu vurgulamaktadır. ${ }^{63}$ Ülkesinde göçmen veya insan kaçakçıları bulunan devletin, kaçakç1lığ 1 öleyecek ve buna son verecek pozitif tedbirler alma yükümlülüğü bulunmaktadır. Bu tür tedbirler ülkesel yargı yetkisine girmektedir ki iç hukuk sisteminde mevcut olan yollarla soruşturma ve cezalandırmayı içermektedir.

Göçmenlere yönelik insan hakları ihlallerini önlemede sorumluluk sahibi her devletin özen gösterme yükümlülüğü vardır. Örneğin, BM GK 2240 Sayılı kararı, göçmen kaçakçılığı ve insan ticareti ile uğraşan organize suç örgütlerini ve can kaybını önlemeyi amaçlamakta olup, bireylerin insan haklarına zarar vermeyi veya uluslararası insan hakları hukuku ve uluslararası mülteci hukuku kapsamında koruma talep etmelerini engellemeyi amaçlamamaktadır. ${ }^{64} \mathrm{Bu}$ nedenle, göçün ulus ötesi etkisi, zorunlu olarak birden çok devletin ve ayrıca Avrupa Birliği gibi bölgesel örgütlerin ortak sorumluluklarını içermektedir. Birden çok devletin özen gösterme yükümlülüğündeki başarısızlığı, haksız fiil üzerinde müşterek bir sorumluluk durumu ile sonuçlanabilmektedir. Örneğin, AİHM'in M.S.S. v. Belçika ve Yunanistan davasında, "başvurucu, Yunanistan'a geldiği andan itibaren içinde bulunduğu sefil durumun, 3 . madde'nin manasıyla insanlık dışı ve onur kırıcı muameleye eşdeğer olduğunu ileri sürmüştür” ve mahkeme Yunanistan'in 3. maddeyi “dolaylı olarak" ihlal ettiği hükmünü vermiştir. ${ }^{65}$ Belçika'nın müşterek sorumluluğu ile ilgili olarak ise, başvurucuyu Yunanistan'a göndererek onu onur kırıcı muamele teşkil eden gözaltı ve yaşam koşullarına bilinçli olarak maruz bıraktığına karar vermiştir. ${ }^{66}$ Geri göndermeme kuralını ihlal eden devlet, bir göçmeni, doğrudan devlet yetkililerinin neden olduğu ciddi insan hakları ihlallerine maruz kaldığ 1

62 Madde 3, Sınıraşan Örgütlü Suçlara Karşı BM Sözleşmesine Ek Kara, Deniz ve Hava Yoluyla Göçmen Kaçakçılığı Karşı Protokol, 5 Kasım 2000, UNTS 2241.

63 BM Güvenlik Konseyi Rezolüsyon 2240, Giriş.

${ }^{64}$ BM Güvenlik Konseyi Rezolüsyon 2240, para. 12.

65 M.S.S/Belçika ve Yunanistan, para. 286 ve özellikle para.235-264. Davanın Türkçe metni için bakınız: <http://www.multeci.org.tr/wp-content/uploads/2016/12/M.S.S.-Belcika-veYunanistan.pdf> Erişim Tarihi: 03.03.2021.

66 M.S.S / Belçika ve Yunanistan, para.323-368. 
IIIIIIIIII!

üçüncü bir devlete aktarırsa, hedef devlet ile birlikte ortak sorumlu olmaktadır. O halde açık denizlerde göçmenleri geri göndermemenin ülke dişı etkisi nedir?

\section{Denizlerde Göçmenleri Geri Göndermemenin Ülke-Dışı Etkisi}

Göçmenler, uluslararası hukuk kapsamında tanınan asgari insan hakları koruma standartlarının sağlamış olduklarından çok daha düşük insan hakları koruma standartlarına sahip olmaktadırlar. ${ }^{67}$ Denizlerde, göçmenlerin temel insan haklarını korumada menşe devleti ya da uyruğu olduğu devlet isteksiz olabilmekte veya yeterli korumayı gerçekten sağlayamamaktadır. Diğer taraftan, genellikle hedef devlet söz konusu olduğunda, göçmenler kendi topraklarına girene kadar onları koruma sorumluluğuyla ilgilenmemekte hatta göçmenlerin kendi sınırlarına ulaşmalarını önlemekte ya da başka ülkelere geri itme yetkilerini kullanabilmektedirler. Öyle ki bu durum açık denizler söz konusu olduğunda, menşe, geçiş ve hedef ülkeleri arasında müdahale etme yetkisi sorunu daha belirgin hale gelmektedir. ${ }^{68}$

Son yıllarda, devletler "geri itme/push back" ${ }^{9}$ politikaları yoluyla göçün yükünden kurtulmaya çalışmaktadırlar. ${ }^{70}$ Bu politikalar, denizde meydana gelen ölüm oranlarının artmasına veya bir kişinin geri gönderilmeden önce terk ettiği ülkeye geri dönmesi durumunda maruz kalabileceği insan hakları ihlalleri gibi olası risklere neden olmaktadır. Bununla birlikte, devletlerin koruma görevi,

67 Maddeler 31 (1) ve 33 (1) (2) Mültecilerin Hukuki Statüsüne İlişkin Sözleşme, Maddeler 2(1), 6 (1) ve 7 Medeni ve Siyasi Haklara İlişkin Uluslararası Sözleşme, Madde 3 (1) İşkenceye ve Diğer Zalimane, İnsanlık dışı ya da Aşağılayıcı Muamele ya da Cezaya Karşı Sözleşme, Maddeler 1, 2(1) ve 3 Avrupa İnsan Hakları Sözleşmesi.

$68 \mathrm{Bu}$ duruma en iyi örnek, 2011 yılında yakıtı biten Libya'dan kaçan göçmenlerle ilgili "Ölmeye Terkedilen Tekne/Left-to-die Boat" verilebilir. Tekrar tekrar acil durum çağrıları göndermelerine rağmen, bölgede faaliyet gösteren devletlerin ve devlet-dışı aktörlerin hiçbiri göçmenlere yardım sağlamamıştır. Göçmenler, Libya kıyılarına tekrar ulaşana kadar geçen 14 gün boyunca denizde terkedilmiş ve 72 göçmenden sadece 9'u hayatta kalmıştır. Charles Heller, Lorenzo Pezzani and Situ Studio, 'Forensic Oceanography. Report on the "Left-ToDie Boat"', <https://www.fidh.org/IMG/pdf/fo-report.pdf>, Erişim Tarihi: 03.03.2021.

69 Human Rights Watch, 'Pushed Back, Pushed Around - Italy's Forced Return of Boat Migrants and Asylum Seekers, Libya's Mistreatment of Migrants and Asylum Seekers', Sept. 2009, <http://www.hrw.org/en/node/ 85585> Erişim Tarihi: 03.03.2021, UNHCR Press Releases, 'Follow-up from UNHCR on Italy's push-backs', 12 May 2009, <http:// www.unhcr.org/4a0966936.html> Erişim Tarihi: 03.03.2021; UNHCR Press Releases, 'UNHCR deeply concerned over returns from Italy to Libya', 7 May 2009, <http://www. unhcr.org/4a02d4546.html> Erişim Tarihi: 03.03.2021, BBC News, 'Libya given migrant patrol boats', 15 May 2009, <http://news.bbc.co.uk/2/hi/europe/8051557.stm> Erişim Tarihi: 03.03.2021.

70 Violeta, Moreno-Lax, 'Seeking Asylum in the Mediterranean: Against a Fragmentary Reading of EU Member States' Obligations Accruing at Sea', (2011) 23 International Journal of Refugee Law 181, UNHCR, "Follow-up from UNHCR on Italy's push-backs" (2009) Briefing notes, < https://www.unhcr.org/4a0966936.html> Erişim Tarihi: 02.03.2021. 
göçmenlerin kendi topraklarının dışında veya ülke dışında gerçekleşebilecek insan hakları ihlalleri riskiyle karşı karşıya kalmaları durumunda dahi, ülke dışına uzanıyor olması gerekmektedir. Devletlerin, göçmenlerin kendi bölgelerine ulaşmalarını engellemeye yönelik bu politikaları tasarlarken, bu görevin açık denizlere kadar uzandığını (açık denizleri de içine aldığını) dikkate almaları gerekmektedir.

Devletlerin ülke dışı mücadeleleri arasında, denizlerde yakalanan veya kurtarılan göçmenlerin geri dönme süreci ve göçmenleri taşıyan botları kendi yetki alanlarının dışına çıkmaya zorlamaları ile çok sayıda devlet tarafından uygulanan "geri itme / push-back" denizde gerçekleştirilen geri itme ya da sınır denetimi operasyonları sırasında hem mülteci hukukuna ve insan haklarına saygılı davranılmalı hem de bu operasyonlar uluslararası deniz hukuku ile uyumlu olmalıdırlar. ${ }^{72}$ AİHM bir devlet tarafından açık denizde kontrol edilen kişilerin, o devletin yargı alanına girebileceğini birkaç dava kararında dile getirmektedir. ${ }^{73}$

AİHM'nin Büyük Dairesi, örneğin İtalya'ya karşı açılan bir davada, Avrupa topraklarını hedef alan göçmenlerin haklarını ve devletlerin yükümlülüklerini ortaya koymaktadır. AİHM, Hirsi Jamaa ve diğerleri / İtalya $^{74}$ davasında başvuranlar, 11 Somali vatandaşı ve 13 Eritre vatandaş, Libya'dan ayrılan ve Lampedusa'ya giden üç teknede yer alan göçmenlerdir. Olayda tekneler, Malta'nın yetki alanında bulunan, deniz arama kurtarma alanının içindeyken (SAR) İtalyan yetkililer tarafından durdurulmuştur. Tüm göçmenler, ikili anlaşmalar ışığında İtalyan askeri gemilerine nakledilmiş ve Libya'ya geri gönderilmişlerdir. AİHM, "uluslararası deniz hukukunun ilgili hükümleri gereğince, açık denizlerde yol alan bir deniz aracının, bandırasını taşıdığı Devlet'in yetki alanına tabi olduğunu" ve bu ilke gereğince, "bir Devletin bayrağını taşıyan gemilerde gerçekleştirilen işlemleri ilgilendiren hallerde, o Devlet'in yetki alanını ülke dışında kullandığına" hükmetmiştir. ${ }^{75}$ Başkaları üzerinde kontrol uygulanması, hükmen (de jure), söz konusu Devlet tarafından ilgili bireyler üzerinde kontrol uygulanması anlamına gelmektedir. ${ }^{76}$ Ayrıca AİHM'in değerlendirmesine göre, "başvuru sahipleri, İtalyan silahlı

71 Bakınız Dipnot 5.

72 Avrupa Birliği Temel Haklar Ajansı, Sığınma, Sinırlar ve Göç ile ilgili Avrupa Hukuku El Kitabl (Avrupa Konseyi, 2014) 37-38.

73 ibid. Dava örnekleri için bakınız: Xhavara ve Diğerleri / İtalya ve Arnavutluk (Application no. 39473/98, AİHM, Karar tarihi: 11 Ocak 2001); Medvedyev ve diğerleri / Fransa, (Başvuru no. 3394/03, AİHM, Karar tarihi: 29 Mart 2010).

74 Hirsi Jamaa ve diğerleri / İtalya (Başvuru no. 27765/09, AİHM, Karar tarihi: 23 Şubat 2012), (Hirsi Jamaa v. Italy, Application No.27765/09, ECtHR, Judgement of 23 February 2012).

75 Hirsi Jamaa ve diğerleri / İtalya, para. 77.

76 Hirsi Jamaa ve diğerleri / İtalya, para. 77. 
IIIIIIIIII!

kuvvetlerine ait gemilere bindirilmeleriyle Libya makamlarına teslim edilmeleri arasında geçen sürede, İtalyan makamlarının devamlı ve münhasır hükmi (de jure) ve fiili (de facto) kontrolü altında bulunmuşlardır". ${ }^{77}$ Devletlerin, vatandaş olmayanların kendi topraklarındaki girişini, ikametini ve sınır dışı edilmesini kontrol etme hakkına sahip olduğunu kabul etmekle birlikte, bu hak genel uluslararası hukuka ve Avrupa İnsan Hakları Sözleşmesi'ne (AİHS) tabidir. $^{78}$ İtalya, göçmenleri Libya'ya geri göndererek, Sözleşmenin 3.maddesi uyarınca yasaklanan kötü muamelenin yanı sıra zorla geri gönderilme riskine maruz bırakmıştır. ${ }^{79}$

Ayrıca, Mahkeme oldukça önemli bir noktada, mahkemeye başvuranların gemilerinin durdurulmasının ve transit devlet tarafından geri gönderilmelerinin, yabancıların toplu olarak sınır dışı edilmesini yasaklayan 4 No'lu Protokol'ün 4. Maddenin ihlali teşkil edip etmediğini değerlendirmiştir. ${ }^{80}$ AİHM, "egemen otoritesini uygulayan bir Devletin makamları tarafından açık denizlerde yapılan bir durdurma bağlamında yabancıların geri gönderilmelerinin, göçmenlerin Devletin sınırlarına ulaşmalarına engel olma ve hatta onları başka bir Devlete geri itme etkisi olduğu ve söz konusu Devletin 4 No.lu Protokol'ün 4. maddesi kapsamında sorumluluğunu devreye sokan bir sınır ötesi yarg1 yetkisi kullanımı teşkil ettiğgi’"sı sonucuna varmıştır. Bu nedenle, 4. No'lu Protokol'ün

77 Hirsi Jamaa ve diğerleri / İtalya, para. 81.

78 Hirsi Jamaa ve diğerleri / İtalya, para.113.

79 Hirsi Jamaa ve diğerleri / İtalya, para. 138.

80 Hirsi Jamaa ve diğerleri / İtalya, para.169-182:

"Mahkeme, Sözleşme'nin metninde veya hazırlık çalışmalarında (travaux préparatoires) söz konusu hükmün sınır ötesi uygulamasının engellenmediğini gözlemlemiştir. 4 No.lu Protokolü hazırlayanlara göre, "sınır dışı" teriminin "mevcut halde kullanıldığı genel anlamıyla (bir yerden uzaklaştırmak)" şeklinde yorumlanması gerekmektedir. Ayrıca, eğer 4 No.lu Protokol'ün 4. maddesi sadece yabancıların Sözleşme'ye Taraf Devletlerin ulusal topraklarından toplu olarak sınır dışı edilmelerine uygulanabilir olsaydı, güncel göç modellerinin önemli bir bileşeni söz konusu hükmün kapsamına girmezdi ve sıklıkla yaşamlarını tehlikeye atarak denize açılan ve bir Devletin sınırlarına ulaşmayı başaramayan göçmenlerin, kara yoluyla seyahat eden göçmenlerin aksine sınır dışı edilmeden önce kişisel koşullarının incelenmesini talep etme hakları bulunmazdı. Sınır dışı etme kavramının, tıpk1 "yetki alanı" kavramı gibi öncelikli olarak ülkesel nitelikte olduğu açıktır. Fakat Mahkeme bir Devletin istisnai olarak yargı yetkisini ulusal topraklarının dışında kullandığını tespit ederse, Devletin sınır ötesi yargı yetkisi kullanımının topluca sınır dışı biçimini aldığını kabul edebilir. Mahkeme ayrıca, deniz ortamının sahip olduğu özel niteliğinin, denizleri hukukun dışında bir alan kılmadığını vurgulamıştır.”

81 Hirsi Jamaa ve diğerleri / İtalya, para.169-182; AİHM, Avrupa İnsan Hakları Sözleşmesi’ne Ek 4 No.lu Protokol'ün 4. Maddesine İlitkin Rehber: Yabanciların Topluca Sinır Dışı Edilmeleri Yasağı, Avrupa Konseyi, (2020) 5 <https://inhak.adalet.gov.tr/Resimler/ Dokuman/482020113746Guide\%20Art-4-Protocol-4-\%20TUR.pdf> Erişim Tarihi: 12.03.2021. 
4. maddesinden kaynaklanan yükümlülükler ülke dişı olarak geçerlidir. ${ }^{82}$ Mahkeme, kișilerin açık denizlerde korunmalarının AİHS'nin yetki alanı dışında olduğunu açıkça reddetmektedir. Mahkemeye göre, göç politikaları AİHS yükümlülüklerine aykırı olmamalı ve "anlaşmaların hükümleri, amaç ışığında iyi niyetle ve anlaşmanın amacı ve etkililik ilkesine uygun olarak yorumlanmalıdır". ${ }^{83}$

AİHM, Hirsi Jamaa ve diğerleri / İtalya davasında ilk kez açık bir şekilde sınır ötesi göçmenlik kontrol tedbirini ele almış ve insan hakları kapsamına yerleştirmiştir. ${ }^{84}$ AİHM böylece, geri göndermeme yükümlülüklerinin yalnızca ulusal topraklarda geçerli olduğu veya göçmenlerin resmi kanalların dışındaki bir bölgeye girmeye çalıştıklarında koruma haklarını kaybettikleri görüşlerini savunan iddiaları bu kararla birlikte reddetmiştir. ${ }^{85}$ Devletler, temel egemenlik konuları ile ilgili olsalar bile tüm faaliyetlerinde insan hakları hukuku sorumluluğu altındadırlar.

Devletler bazen deniz ortamından kaynaklanan pratik zorluklara veya deniz hukuku kapsamındaki yükümlülüklerine atıfta bulunarak bu tür davranışları haklı çıkarmaya çalışmışlardır. Hirsi Jamaa ve diğerleri / İtalya davasında, İtalya denizde tehlikede olan kişilerin kurtarılmasını gerektiren Deniz Hukuku Sözleşmesi'nin 98 (1) (b) maddesi gereği yerine getirmektedir. ${ }^{86}$ Mahkeme, "deniz çevresinin özel niteliğinin, bireylerin Devletleri'n yetki alanlarında bulunan herkes için temin etmeyi taahhüt ettiği Sözleşme tarafından verilen hak ve güvencelerden yararlanmalarını sağlayacak hiçbir hukuk sistemi tarafından korunmadıkları hukuk dışı bir alanın varlığını haklı kılamayacağını" belirtmiştir. ${ }^{87}$ Aslında, ne Deniz Hukuku Sözleşmesi ne de diğer deniz hukuku kurallarındaki hiçbir şey (Denizcilik Arama ve Kurtarma Sözleşmesi gibi) devletlerin insan hakları gerekliliklerine uymasını engellememektedir. ${ }^{88}$

82 AİHM, 2020 yılında vermiş olduğu N.D ve N.T / İspanya kararı ile polislerin sınırlarda geri itme yoluyla göçmenleri topluca sınır dışı edilmeleri yasağı kapsamında ihlal bulmamış, bu durum Hirsi kararı ile yasa dışı yollarla giriş yapan göçmenleri geri itmeyeceği kararının tam tersi bir karar vermiştir. Nitekim bu karar AİHM'e yöneltilen eleştirilere sebep olmuştur. N.D ve N.T / İspanya kararı (Başvuru no. 8675/15, AİHM Karar tarihi: 13 Şubat 2020) (N.D and N.T v. Spain, App. No. 8675/15, ECtHR Judgement given of 13 February 2020), Mart ayında tekrar benzer bir karar vermiştir. Bakınız: Asady ve diğerleri/Slovakya, (Başvuru no. 24917/15, AİHM, Karar tarihi: 24 Mart 2020).

83 Hirsi Jamaa ve diğerleri / İtalya, para. 180

84 Lisa Heschl, "Extraterritorial Immigration Control Measures by EU Member States", in Lisa Heschl (edt.), Protecting the Rights of Refugees Beyond European Borders: Establishing Extraterritorial Legal Responsibilities (Intersentia, 2018) 80-81. ibid.

86 Hirsi Jamaa ve diğerleri / İtalya, para. 65.

87 Hirsi Jamaa ve diğerleri / İtalya, para. 178.

88 Irini Papanicolopulu, 'Hirsi Jamaa v. Italy. Application No. 27765/09' (2013) 107(2) American Journal of International Law, 417-423, 422-23. 
IIIIIIIIII!

Dolayısıyla, deniz hukuku sözleşmesinin dışında, insan hakları hukuku aynı zamanda devletlere açık denizlerde de insan hayatını koruma görevinde yükümlülük getirmektedir.

Özetlemek gerekirse, AİHM Hırsi kararı ile, geri göndermeme ilkesini uluslararası mülteci hukuku çerçevesinden yani kapsamından çıkartarak açık denizlerle ilgili insan hakları hukuku bağlamına yerleştirerek bu tür devlet uygulamalarına bir meydan okuma sunmaktadır. ${ }^{89}$ İnsan hakları hukukunda, geri göndermeme yükümlülügünün uygulama kapsamı devletlerin bölgeleri ile sınırlı değildir. Geri göndermeme ilkesi, "iltica ve uluslararası mülteci hukukunun temel taşı" olarak kabul edildiğinden, sınırlayıcı dış göç kontrollerinin yaşandığı bir çağda bu ilkenin ülke dışı uygulaması büyük önem taşımaktadır. ${ }^{90}$ Diğer taraftan, pozitif özen yükümlülüklerinin normalde devletlerin ülkesel yetki kapsamında olarak düşünüldüğünü, başka bir deyişle, özen gösterme yükümlülüklerinin "bölgesel karakterini koruduğunu" belirtmek önemlidir. ${ }^{91}$ Buna göre, dış göç kontrolleri bağlamında pozitif yükümlülüklerin ihlali devlet sorumluluğunu doğurmamakta, ancak ülke dışı yargı yetkisi söz konusu olduğunda, devlet sorumluluğu konusunu tetikleyecek şekilde pozitif yükümlülüklere etki etmektedir. ${ }^{92}$ Sonuçta, devlet sorumluluğundan ziyade ülke-dış11k etkisini içermektedir.

\section{SONUÇ}

Göç, çok sayıda devletin ortak sorumluluğunu içeren ulus ötesi bir fenomen olmasına rağmen, devletler genellikle göçmenleri korumak konusunda isteksiz ve yetersiz kalmaktadırlar. Hedef ve geçiş devletleri, göçmenlerin kendi bölgelerine girinceye kadar göçmen sorunlarıyla uğraşmaktan kaçınmakta, açık denizlerde bu durum yeni bir yere sığınma riskini alan göçmenlerin ölümlerine neden olmaktadır. Bu makale, uluslararası insan hakları hukukunun pozitif yükümlülüğü olan özen yükümlülüğü ilkesi bağlamında, devletlerin kendi topraklarında olmasa bile göçün ülke dış1 etkisini göz önünde bulundurarak göçmenlere karşı koruma görevinde sorumlu olduklarını analiz etmektedir. $\mathrm{Bu}$ analiz, Uluslararası Mülteci Hukuku, Uluslararası Deniz Hukuku ve İnsan Hakları Hukuku arasındaki ilişki bağlamında göçün ülke dışı etkisini

89 A. M. North, 'Extraterritorial Effect of Non-Refoulement', The International Association of Refugee Law Judges World Conference, 7-9 September 2011, <https://www.refworld.org/ pdfid/557030f64.pdf> Erişim Tarihi: 22.03.2021.

90 UN High Commissioner for Refugees, UNHCR Note on the Principle of Non-Refoulement, November 1997, <https://www.refworld.org/docid/438c6d972.html> Erişim Tarihi: 22.03.2021.

91 Seunghwan Kim, "Non-refoulement and extraterritorial jurisdiction: State sovereignty and migration controls at sea in the European context" (2017) 30(1) Leiden journal of international law 49-70, 66-67.

92 ibid. 
denizlerde geri göndermeme ilkesi (non-refoulement principle) uyarınca tüm göçmenlere karş1 ortak koruma görevinde özen gösterme sorumluluğu çerçevesinde yapılmıştır.

Ülke dışında meydanagelen insan hakları ihlalleriiçin devletsorumluluğunun üstlenilebileceğini doğrulayan emsaller varken, bu tür sorumluluk özellikle Avrupa'da belirli bir devletin toprak veya kişiler üzerinde uyguladığı kontrolün ülke dışı etkililiği kriterine göre koşullandırılmıştır. ${ }^{93} \mathrm{Bu}$ durum, ihlalin devletin yargılama yetkisine girip girmediğini belirlemeye izin vermektedir. Denizlerdeki göçmenler söz konusu olduğunda, uluslararası hukukun, devletlere açık denizlerdeki göçmenleri kurtararak insan hayatını korumak için harekete geçme yükümlülüğü getirip getirmediği konusunda önemli bir sorun ortaya çıkmaktadır. Koruma görevinin belirli koşullar altında sınırlamalara tabi olmasına rağmen, insan hakları hukuku birçok devlete açık denizlerde de koruma görevi yükümlülüğü vermektedir. Sonuç olarak, göçmenlere böylesi ülke dışı koruma sağlamadaki başarısızlıklarından dolayı devletleri sorumlu tutmak özen yükümlülüğü ilkesi gereği mümkün olabilmektedir.

\section{KAYNAKÇA}

AİHM, Avrupa İnsan Haklar Sözleşmesi'ne Ek 4 No.lu Protokol'ün 4. Maddesine İlitkin Rehber: Yabanclların Topluca Sinır Dışı Edilmeleri Yasağl, Avrupa Konseyi, (2020) $5<$ https://inhak.adalet.gov.tr/Resimler/ Dokuman/482020113746Guide\%20Art-4-Protocol-4-\%20TUR.pdf> Erişim Tarihi: 12.03.2021.

Application of the Convention on the Prevention and Punishment of the Crime of Genocide (B.H. v. S.M.), Judgment, 2007 I.C.J. 43.

Arbour, L. 'The Responsibility to Protect as a Duty of Care in International Law and Practice', (2008) 34 Review of International Studies 445-458.

Asady ve diğerleri/Slovakya, (Başvuru no. 24917/15, AİHM, Karar tarihi: 24 Mart 2020).

Avrupa Birliği Temel Haklar Ajansı, Sığınma, Sınırlar ve Göç ile ilgili Avrupa Hukuku El Kitabl (Avrupa Konseyi, 2014)

Bankovic and others v. Belgium, the Czech Republic, Denmark, France, Germany, Greece, Hungary, Iceland, Italy, Luxembourg, the Netherlands, Norway, Poland, Portugal, Spain, Turkey and the United Kingdom, (Application No. 52207/99, Judgement of 12 December 2001).

Barnes, R., 'Refugee Law at Sea', (2004) 53 International and Comparative Law Quarterly 48-61.

93 Fons Coomans and Menno T. Kamminga, Extraterritorial Application of Human Rights Treaties (Intersentia, Antwerp- Oxford, 2004). 
IIIIIIIIII!

Barnidge, R. P., 'The Due Diligence Principle under International Law', 8 International Community Law Review (2006) 81-122.

BBC News, 'Libya given migrant patrol boats', 15 May 2009, <http://news. bbc.co.uk/2/hi/europe/8051557.stm> Erişim Tarihi: 03.03.2021.

BM Deniz Hukuku Sözleşmesi/United Nations Convention on the Law of the Sea (UNCLOS), 10 December 1982, unts 1833. Türkçe metni için bakınız: $<$ http://www.turkishgreek.org/kuetuephane/item/153-unclos-turkish $>$ Erişim Tarihi: 02.03.2021.

Bonnitcha J. and McCorquodale, R., "The Concept of "Due Diligence" in the UN Guiding Principles on Business and Human Rights', (2017) 28(3) EUR. J. INT'L L. 899.

Coomans, F. and Kamminga, M. T., Extraterritorial Application of Human Rights Treaties (Intersentia, Antwerp- Oxford, 2004).

Uluslararası Haksız Fiillerden Ötürü Devletin Uluslararası Sorumluluğu Taslak Metin /Draft Articles on Responsibility of States for Internationally Wrongful Acts with Commentaries 2001, Yearbook of the International Law Commission, 2001, <https://legal.un.org/ilc/texts/instruments/english/ commentaries/9_6_2001.pdf> Erişim Tarihi: 12.02.2021.

Ertürk, Y., 'The Due Diligence Standard as a Tool for the Elimination of Violence Against Women', U.N. Doc. E/CN.4/2006/61 (Jan. 20, 2006).

Fallon, F., "'We were left in the sea': asylum seekers forced off in Lesbos", (19 March 2021) The Guardian, available at: < https://www.theguardian. com/global-development/2021/mar/19/asylum-seekers-forced-off-lesbospushback-crisis-europe-borders> Erişim Tarihi: 18.04.2021;

French, D. and Stephens T. (Rapporteurs), International Law Association Study Group on Due Diligence in International Law, ILA Study Group, First Report, 7 March 2014.

Giuffré, M., "Access to Asylum at Sea? Non-refoulement and a Comprehensive Approach to Extraterritorial Human Rights Obligations", in Violeta MorenoLax and Efthymios Papastavridis (eds.), Boat Refugees' and Migrants at Sea: A Comprehensive Approach (Brill Nijhoff, 2017) 248-275.

Goodwin-Gill, G. S., "Setting the Scene: Refugees, Asylum Seekers, and Migrants at Sea-the Need for a Long-term, Protection-Centred Vision", in Violeta Moreno-Lax, and Efthymios Papastavridis (eds.), Boat Refugees' and Migrants at Sea: A Comprehensive Approach (Brill Nijhoff, 2017) 17-31.

Goodwin-Gill, G. S., 'International refugee law: Where it comes from, and where it's going' (2017) 45 Int'l J. Legal Info. 24. 
Guilfoyle, D., "Transnational crime and the rule of law at sea: responses to maritime migration and piracy compared", in Violeta Moreno-Lax and Efthymios Papastavridis (eds.), 'Boat Refugees' and Migrants at Sea: A Comprehensive Approach, (Brill Nijhoff, 2017) 169-196.

Hathaway, J. C. M., The rights of refugees under international law (Cambridge University Press, 2005).

Hathaway, J. C. and Foster, M., The Law of Refugee Status (Cambridge University Press, 2014).

Heller, C., Pezzani, L. and Studio, S., 'Forensic Oceanography. Report on the "Left-To-Die Boat", <https://www.fidh.org/IMG/pdf/fo-report.pdf $>$, Erişim Tarihi: 03.03.2021.

Heschl, L., "Extraterritorial Immigration Control Measures by EU Member States", in Lisa Heschl (edt.), Protecting the Rights of Refugees Beyond European Borders: Establishing Extraterritorial Legal Responsibilities (Intersentia, 2018) 47-140.

Hessbruegge, J. A., 'The Historical Development of the Doctrines of Attribution and Due Diligence in International Law', (2004) 36 N.Y.U. J. INT'L L. \& POL. 265.

Hirsi Jamaa ve diğerleri / İtalya (Başvuru no. 27765/09, AİHM, Karar tarihi: 23 Şubat 2012), (Hirsi Jamaa v. Italy, Application No.27765/09, ECtHR, Judgement of 23 February 2012).

Human Rights Watch, 'Pushed Back, Pushed Around - Italy's Forced Return of Boat Migrants and Asylum Seekers, Libya's Mistreatment of Migrants and Asylum Seekers', Sept. 2009, <http://www.hrw.org/en/node/ 85585> Erişim Tarihi: 03.03.2021.

International Court of Justice, Case Concerning the Application of the Convention on the Prevention and Punishment of the Crime of Genocide, (judgement of 26 February 2007).

International Organization for Migration, 'December 2020 update - NGO ships involved in search and rescue in the Mediterranean and legal proceedings against them' <https://fra.europa.eu/en/publication/2020/december-2020update-ngo-ships-involved-search-and-rescue-mediterranean-and-legal $>$ Erişim Tarihi: 12.02.2021.

International Organization for Migration, Missing Migrants Project (Web Page) $<$ http://missingmigrants.iom.int $>$ Erişim tarihi: 12.02.2021. 
IIIIIIIIII!

Kamminga, M. T., “"Due diligence” Mania: The Misguided Introduction of an Extraneous Concept into Human Rights Discourse', in Ingrid Westendorp (ed.), The Women's Convention Turned 30 (Maastricht Faculty of Law Working Paper No. 2011/07, 2012) 407-417.

Kim, S., "Non-refoulement and extraterritorial jurisdiction: State sovereignty and migration controls at sea in the European context" (2017) 30(1) Leiden journal of international law 49-70.

Komp, L. M., "The Duty to Assist Persons in Distress: An Alternative Source of Protection against the Return of Migrants and Asylum Seekers to the High Seas?", in Violeta Moreno-Lax and Efthymios Papastavridis (eds.), 'Boat Refugees' and Migrants at Sea: A Comprehensive Approach, (Brill Nijhoff, 2017), 222-247.

Mazzeschi, R. P. 'The Due Diligence Rule and the Nature of the International Responsibility of States', (1992) 35 German Yearbook of International Law, 9-51.

McKErnan, B., "Greece accused of 'shocking' illegal pushback against refugees at sea" (26 April 2021) The Guardian, available at: < https://www.theguardian. com/world/2021/apr/26/greece-accused-of-shocking-pushback-againstrefugees-at-sea?CMP=Share_iOSApp_Other $>$ Erişim Tarihi: 28.04.2021.

MCNEILL, W. H., 'Human Migration in Historical Perspective', (1984) 10 (1) Population and Development Review, 1-18.

Mediterranean: Dead and Missing at Sea, United Nations High Commissioner for Refugees, <http://data2.unhcr.org/en/situations/mediterranean $>$ Erişim tarihi: 12.02.2021.

Medvedyev ve diğerleri / Fransa, (Application no. 3394/03, Judgment of 29 Mart 2010).

Milanovic, M., Extraterritorial Application of Human Rights Treaties: Law, Principles, and Policy, (Oxford University Press, 2011)

Moreno-Lax, V., 'Seeking Asylum in the Mediterranean: Against a Fragmentary Reading of EU Member States' Obligations Accruing at Sea', (2011) 23 International Journal of Refugee Law 181.

M.S.S v Belgium and Greece, (Application No. 30696/09, Judgment of 21 January 2011).

N.D ve N.T / İspanya kararı (Başvuru no. 8675/15, AİHM Karar tarihi: 13 Şubat 2020) (N.D and N.T v. Spain, App. No. 8675/15, ECtHR Judgement given of 13 February 2020) 
North, A. M., 'Extraterritorial Effect of Non-Refoulement', The International Association of Refugee Law Judges World Conference, 7-9 September 2011, $<$ https://www.refworld.org/pdfid/557030f64.pdf> Erişim Tarihi: 22.03.2021.

Osman v. UK, (Application No. 23452/94, Judgment of 28 October 1998).

Othman (Abu Qatada) v. United Kingdom, (Application No. 8139/09, Judgment of 17 January 2012).

ÖNER, A. Ş., “Göç Çalışmalarında Temel Kavramlar”, in Aslı Ş. ÖNER ve Gülfer Ihlamur Öner (edt.), Küreselleşme Çă̆ında Göç: Kavramlar, Tartışmalar (İstanbul: İletişim Yayınları, 2012) 13-27

ÖNGÖR, S., Coğrafya Terimleri Sözlüğü, (Ankara: Türk Dil Kurumu Yayınlar1, $1980)<$ http://tdkterim.gov.tr/>, Erişim Tarihi: 16.02.2017.

Papanicolopulu, I., 'Hirsi Jamaa v. Italy. Application No. 27765/09' (2013) 107(2) American Journal of International Law, 417-423.

Remarks by Peter D. Sutherland, UN Special Representative for International Migration Before the United Nations Security Council, May 11, 2015, $<$ https://www.un.org/en/development/desa/population/migration/partners/ docs/Remarks_by_SRSG_PeterSutherland_on_SecurityCouncil.pdf.> Erişim Tarihi: 12.02.2021.

Sınıraşan Örgütlü Suçlara Karşı BM Sözleşmesine Ek Kara, Deniz ve Hava Yoluyla Göçmen Kaçakçılığı Karşı Protokol, 5 Kasım 2000, UNTS 2241.

Smith, H., "Cyprus rebuked for 'violent' pushbacks of boats carrying asylum seekers", (18 March 2021) The Guardian, available at: < https://www. theguardian.com/world/2021/mar/18/watchdog-criticises-cyprus-treatmentasylum-seekers> Erişim Tarihi: 18.04.2021.

Soykırımı Önleme ve Cezalandırma Sözleşmesi (Convention on the Prevention and Punishment of the Crime of Genocide, opened for signature Dec. 9, 1948, 78 U.N.T.S. 277, yürürlülük tarihi: 12 Ocak 1951).

Stalker, C., 'Jurisdiction', in M.D. Evans (ed.), International Law (4th edn, Oxford University Press, Oxford, 2014) 309-335.

Stoyanova, V., 'Causation between State Omission and Harm within the Framework of Positive Obligations under the European Convention on Human Rights' (2018) 18 Human Rights Law Review 309-346.

The Haitian Centre for Human Rights et al v. United States, Inter-American Commission of Human Rights, Decision as to the merits of case 10.67513 March 1997, Report No. 51/96. 
Devletlerin Özen Yükümlülüğ̈ İlkesi Bağlamında Denizlerde Göçmenleri Koruma Görevi Dr. Ayşe GÜNEŞ

IIIIIIIIII!

Trevisanut, S., 'Is There a Right to Be Rescued At Sea? A Constructive View', 4 Questions of International Law (June 2014) 3-15.

-'The Principle of Non-Refoulement And the De-Territorialization of Border Control at Sea'(2014) 27(3) Leiden Journal of International Law, 661-675.

UN Human Rights Committee, 'General Comment No. 31: The Nature of the General Legal Obligation Imposed on States Parties to the Covenant', U.N. Doc. CCPR/C/21/Rev.1/Add. 13 (May 26, 2004).

UN High Commissioner for Refugees, UNHCR Note on the Principle of NonRefoulement, November 1997, <https://www.refworld.org/docid/438c6d972. html > Erişim Tarihi: 22.03.2021.

UNHCR, "Follow-up from UNHCR on Italy's push-backs" (2009) Briefing notes, < https://www.unhcr.org/4a0966936.html> Erişim Tarihi: 02.03.2021.

UNHCR Press Releases, 'Follow-up from UNHCR on Italy's push-backs', 12 May 2009, <http://www.unhcr.org/4a0966936.html> Erişim Tarihi: 03.03.2021.

UNHCR Press Releases, 'UNHCR deeply concerned over returns from Italy to Libya', 7 May 2009, <http://www.unhcr.org/4a02d4546.html > Erişim Tarihi: 03.03.2021.

UNHCR, 'Note on international protection' (13 September 2001) a/ac.96/951.

UNSC Resolution 2240 (9 October 2015) un Doc. s/res/2240. Available at: $<$ http://unscr.com/files/2015/02240.pdf > Erişim Tarihi: 22.02.2021.

Xhavara ve Diğerleri / İtalya ve Arnavutluk, Başvuru no. 39473/98, Karar Tarihi: 11 Ocak 2001.

Velásquez- Rodriguez v. Honduras, Judgment, Inter-American Court of Human Rights Series C No. 4 (29 July 1988).

1974 tarihli Denizde Can Güvenliği Uluslararası Sözleşmesi/International Convention on Salvage, 28 April 1989, UNTS. 1953.

1979 Denizde Arama ve Kurtarma Uluslararası Sözleşmesi/International Convention on Maritime Search and Rescue, 27 April 1979, UNTS. 1403.

1989 Uluslararası Kurtarma Sözleşmesi/International Convention for the Safety of Life at Sea, 1 November 1974, UNTS. 1184. 